\title{
S 1-1
}

老化遺伝子p16 ${ }^{\mathrm{INK} 4 \mathrm{a}}$ 誘導による滑膜炎の治療

○上阪 等、谷口 顕、野々村美紀、長坂憲治、井上直已、那須公雄、宮坂信之 (東京医科歯科大学 第一内科)

〔目的〕慢性関節リウマチ(RA)の関節破墑の原因である滑膜細胞の增殖を直接的に阻止する新 治潦法を開発する。

[方法] RA、骨関節症 $(O A)$ 䍜患患者の滑膜組織や正常滑膜組織、またこれらの滑膜に由来する 線維芽細胞および他の線維芽細胞を種々の条件下に置き、サイクリン依存性キナーゼインヒビター (CDKI)群の発現をWesternブロット法で検討する。次に滑膜增殖抑制に重要であったCDKI遺伝子 をアデノウイルスで滑膜細胞に導入し、in vitroの効果を確認し、動物モデルでin vivoの治療効果 を検討する。

〔結果】新鮮滑膜組織ではp $27^{\mathrm{kipl}}$ の発現のみが認められた。OAや正常滑膜由来の培養滑膜線維 芽細胞、皮䖉や肺由来の線維芽細胞を成長抑制するとp21 ${ }^{\mathrm{CP} 1}$ のみが誘導されたが、RA滑膜細胞で

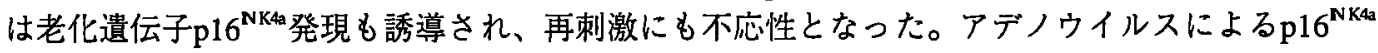
遺伝子導入はRA滑膜細胞のin vitroの増殖を阻止した。さらに、アジュバント関節炎、コラーゲ ン誘導関節炎においてのp16 ${ }^{\mathrm{NK4a}}$ in vivo遺伝子療法は滑膜増生に加えて骨・軟骨破壊をも阻止した。

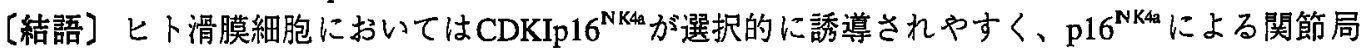
所遺伝子療法は実験関節炎モデルの治療に有効であった。老化遺伝子 $16^{\mathrm{NK4a}}$ の誘導が新たなRA の治療になりうるものと考えられる。

\section{S 1-2}

難治性肪原病の新しい治療戦略

○小林 哲也、岡本 和義、西岡 久寿樹

(聖マリアンナ医科大学・難病治療研究センター・第一部門)

慢性関節リウマチ (rheumatoid arthritis: RA)は、病因不明の難治性自己免疫疾患の一つであり、 現在まで画期的な治療法は開発されていない。我々は、これまでに RA 滑膜組織の増殖性滑膜細 胞ならびに種々の浸潤リンパ球に対して、抗 Fas 抗体および Fas リガンド遺伝子導入細胞によ って積極的なアポトーシスを誘導することが RA の有用な治療手段となり得ることを明示して きた。今回は、RAの新しい治療戦略として、アポトーシス関連遺伝子を用いた、RAの遣伝子治 療の可能性について検討したので報告する。

FADD は、RA 滑膜細胞のみならず多くの細胞において Fas 依存性アポトーシスのシグナル伝 達に重要な分子であり、それ自身の高発現によってもアポトーシスが誘導できることが報告され ている。我々は、滑膜細胞に対して効率よく遺伝子導入できることが知られているアデノウイル スベクターを用いて、FADD 遺伝子を RA 培養滑膜細胞ならびに RA 滑膜組織に遺伝子導入し、 その効果を検討した。

その結果、FADD アデノウイルスは、RA 培羔滑膜細胞に対して著しいアポトーシスを誘導し た。さらに、RA 滑膜組織を SCID マウスに移植したモデルを用い、FADD アデノウイルスを移 植組織に局所注入した結果、アポトーシスによって多くの細胞消失を誘導した。興味深いことに は、FADDアデノウイルスは、軟骨細胞に対してアポトーシスを誘導しなかった。

以上の結果より、FADD 遺伝子を用いた遺伝子治療は、RA の次世代の治療法となりうる可能 性が示された。 


\section{S 1-3}

SLE の病態形成における $\mathrm{T}$ 細胞シグナル伝達、サイトカイン産生異常の解析

○竹内 勤、吉本 桂子、津坂 憲政、安倍 達

（埼玉医科大学総合医療センター 第二内科）

【目的】自己免疫疾患のプロトタイプである SLE の病態には、T細胞の機能異常が関与 する。その分子機序を明らかにするため、 $\mathrm{T}$ 細胞シグナル伝達の各分子に着目して検討 を行った。T細胞ゼー夕鎖を初め、数種類の分子の発現異常が明らかにされたが、それ がどのように病態形成に結びつくか不明であった。そこで、本研究では、シグナル伝達 分子異常によって引き起こされるサイトカイン産生の障害について解析する。

【方法】シグナル伝達分子の発現異常が明かとなっている患者 $\mathrm{T}$ 細胞、および $\mathrm{T}$ 細胞ゼ 一夕鎖ノックアウト細胞株を用いて、抗 CD 3、抗 TCR $\alpha / \beta$ 抗体、TPA, Ionomycin 刺激 によるサイトカイン産生（IL-2, IFN-gamma, IL-4, IL-10, IL-12）を ELISA および半 定量 RT-PCR で検討する。

【結果】SLE 患者 $\mathrm{T}$ 細胞は、TCR ゼー夕鎖の発現低下と平行して、IL-2 産生が低下し たが、IFN-gamma は逆に、発現低下に伴って正常の数十倍もの産生が誘導された。

【結語】SLEのTCR ゼー夕鎖発現低下に伴う病態形成の一要因として、IFN-gamma の過剩産生が示された。これを標的とした治療戦略について考察する。

\section{S 1-4}

SLE患者に対するシクロスポリン療法によるステロイド減量の試み

○田中良哉 ${ }^{1}$, 粟津雄一郎 ${ }^{1}$, 斎藤和義 ${ }^{1}$, 藤井幸 ${ }^{1}$, 大田俊行 ${ }^{2}$, 河野公俊 ${ }^{3}$, 江藤澄哉 ${ }^{1}$

（産業医大・第一内科, ${ }^{2}$ 同・中央検查, ${ }^{3}$ 同・分子生物）

全身性エリテマトーデス(SLE)の臨床では、疾患活動性が極めて高くステロイド単独では治療 が不十分な症例、骨粗琵症、大腿骨頭罟死、感染症等のためステロイドの減量を要するが長用量 投与を余儀なくされる症例を多数経験し、治療に難渋する。今回、ステロイドを長期間長用量使 用し減量が困難なSLE17症例にシクロスポリン(CyA)の併用投与を行った。その結果、14例で臨 床症状・所見、免疫学的検查所見等の改善を認め、ステロイドの減量を可能にした。CyAは、 NFAT阻害を介してIL-2/IL-4等の産生を抑制するが、17例の疾患活動性は軽〜中等度であり、 CyAの直接作用以外の機序が考えられた。CyAは、細胞膜に存在する多剤抵抗性遺伝子(MDR-1) 産物で、抗癌剤やステロイドを細胞外に能動輸送するP-糖蛋白質(P-gp) と拮抗して薬剤耐性を改 善するとされる。実際、長期ステロイドを服用したSLE患者末梢血CD4, CD8, CD19リンパ球で は、P-gp とMDR-1遺伝子転写調節因子YB-1の発現が有意に増加した。さらに、SLE患者リンパ 球では細胞質内ステロイド濃度は減少し、CyA処理により改善した。以上、疾患活動性の高い SLE症例のみならず、ステロイド抵抗性を呈しリンパ球のP-gp高発現を呈するSLE症例でも、ス テロイド抵抗性・低反応性の改善を目的としたCyAの使用を考慮する価值があると思われる。 


\section{S 1-5}

多発性筋炎／皮膚筋炎のステロイド抵抗性間質性肺炎に対する

シクロスポリン療法

○針谷正祥、高木香恵、原まさ子

（東京女子医大膠原病りウマチ痛風センター）

多発性筋炎/皮虚筋炎(PM/DM)ではステロイド抵抗性で予後不良な急速進行性間質性肺 炎を合併することが知られている。近年、このような間質性肺炎(IP)に対するシクロスポ リン(CsA)療法の有効性が注目されてきた。私達は膠原病の IPに対するCsA 療法につい て全国 36 の膠原病専門機関にアンケート調査を行い、報告された 29 例の CsA 投与 PM/DM 症例を解析した。急性型 IP の割合は PM 群 55.5\%（5例）、DM 群 70\%（14 例）であった。 以下急性型 IP について解析を進めた。平均投与量は PM 群 $3.4 、 D M$ 群 $3.9 \mathrm{mg} / \mathrm{kg} / \mathrm{day}$ 、平 均投与期間は PM 群 9.2 か月、DM 群 9.4 か月であった。自覚症状、他覚症状、呼吸機能、 動脈血ガス分析、画像診断、ステロイド減量の 6 項目について評価し、CsA 療法の有効性 を検討した。PM 群では有効 60\%、DM 群では著効 43\%、有効 $29 \%$ という高い有効性を示 した。次に、CsA 療法の適応を検討するためIP 合併 PM/DM 自験例 34 例の解析を行った。 急性活動性 IP16 例中、ステロイド単剤の有効例 6 例、無効例 6 例であった。無効例では $\mathrm{CK} / \mathrm{LDH}$ 、 aldolase/LDH、myoglobin/LDH が有意に低かった。ステロイド剤抵抗例の IP 発 症様式は、ステロイド剤溸減中の IP 急性增恶、PM/DM 寛解中の IP 急性発症、病初期か らの IP 急性発症に分類された。したがって、これらの検查成績および発症様式をとる PM/DM の急性型 IP は治療初期よりステロイド剤にCsA を併用すべきと考えられる。 
S2-1

アデノウィルスベクターを用いたCTLA4Ig遺伝子導入による移植後免疫反応の制御 ○上出利光 ${ }^{2}$, 村上正晃 ${ }^{\mathrm{t}}$, 竹原めぐみ ${ }^{1,2}$, 藤堂 省 ${ }^{2}$

('北大·免疫研・免疫病態, '北大·医・第一外科)

免疫反応の始動には $\mathrm{T}$ 細胞抗原受容体を介する移植片の抗原特異的刺激の他に、宿主 $\mathrm{T}$ 細胞上のCD28と移植片中抗原提示細胞上のB7の結合を介する補助シグナルを必要とする。 我々は、これまでCTLA4の細胞外部分と免疫グロブリンのFC部分融合蛋白、CTLA4Igにより 効果的に急性拒絶反応のみならず慢性拒絶反応を抑制し、移植片の長期生着を得ることが できることを報告してきた。くりかえし投与が必要となる精製CTLA4Igの投与にかわる方 法として、CTLA4Igの遺伝子をアデノウイルスベクター中に組み込んだ、リコンビナント ウイルスを作製した(Adex CTLA4Ig)。Adex CTLA4Igを静注すると、䀒臓で極めて長期間に わたり遺伝子発現が起こり、血中のCTLA4Igを数ヶ月にわたり高值に維持することができ る。しかしながら、高值のCTLA4Igを血中で維持すると、宿主の免疫反応は抑制され、さ らには、補助シグナルの欠失する状件で刺激された $\mathrm{T}$ リンパ球はアナジィーに陥る危険性 がある。そこで我々はCre/10xPシステムを応用したウイルスベクターを開発した。このべ クタ一投与後にCre酵素を含むアデノウイルスベクターを投与しCTLA4Igの遺伝子を切り出 し、CTLA4Igの産生を停止することができる。この0N/0ff adex CTLA4Igを用い、肝移植、 皮膚移植等に対する拒絶反応の制御を試みている。ベクターの持つ長所・短所を含めその 治療効果、作用機序につき概説する。

\section{S 2-2}

遺伝子導入による心臓移植の急性および慢性拒絶の抑制 0 鈴木淳一! 磯部光章? 森下竜- ${ }^{2} 、$ 金田安史 ${ }^{2} 、 川$ 内基裕 ${ }^{3} 、$ 天野 純 $^{4}$ ( ${ }^{1}$ 信州大学第 1 内科、 ${ }^{2}$ 大阪大学遺伝子治療学、 ${ }^{3}$ 東京大学心臓外科、 ${ }^{4}$ 信州大学第 2 外科)

[目的] 心臟移植後の急性㧍よび慢性拒絶の克服は、レシピエントの予媵改善に重要である。 Nuclear Factor-Kappa B(NF-кB)は広く抗原提示や炎症に関与しているが、移植の拒絶反応に おける役割は不明である。この役割を明らかにするために移植心にNF-кBに対するおとり遗伝子

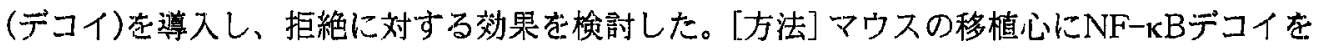
HVJ-liposome法によりex. vivoで導入し、生着の延長をBalb/cマウスからC3H/Heマウスに移 植するモデルで検討した。また、DBAマウスからB10D2マウスに移植するモデルでNF-кBデコ

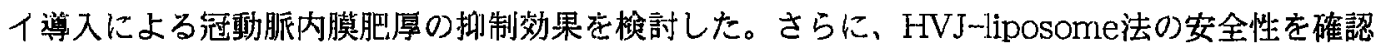
するために、ニホンザル心臓移植モデルでHVJのレシピエント体内での播種の有無を検討した。

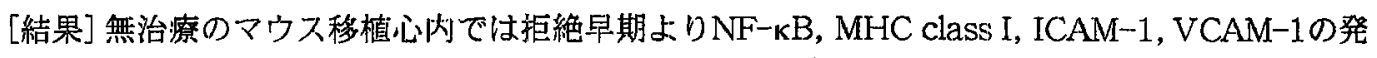
現が増強していた。Balb/cからC3H/Heに移植するモデルでは、遺伝子を道入しない移植心 $(\mathrm{n}=8)$ は平均8日で拒絶されるのに対し、NF有意に延長した。また、DBAからB10D2に移植するモデルで、NF-кBデコイを導入された移植

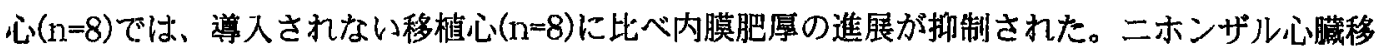
櫵モデルでHVJの他臟器への播種は認められなかった(n=6)。[結論]移植心へのNF-кBデコイ導 入は急性および慢性拒絶の予防に有勒であり、かつ安全であることが示唆された。 
新しい免疫抑制棛と遺伝子導入による免疫制御

○鈴木盛一、李 小康、奥山虎之、田村明彦、舟島直子、絵野沢 伸、 大場正直、雨宮 浩

（国立小児病院 小児医療研究センター・実験外科生体工学部）

免疫抑制剂を作用機序から分類すると、サイトカイン産生阻害剂（シクロスポリン、夕 クロリムス）、核酸合成阻害郕（アザチオプリン、ミゾリビン）、ステロイド剤（プレド ニゾロン、メチルプレドニゾロン）、生物製剂（抗ヒトリンパ球ポリクローナル抗体 A L G、抗ヒトCD３マウスモノクロナール抗体 OKT 3 ) 、およびリンパ球活性阻害剤（塩 酸グスペリムス) がある。これらの薬剂は効果とともにさまざまな副作用があるため、多 くの場合、少量づつを組み合わせた併用療法が行われる。しかし現在のところ、免疫抑制 剂を漸隇することはできるが、原則として一生服用するためさまざまな合併症が問題とな る。したがって、一定期間だけ免疫抑制を行えば、その後は必要なくなる治療法の開発が 待たれる。そこで、我々は以下の 2 つの面からの研究を進めている。一つは、これまでと は全く作用機序の異なる薬郕の開発である。F T Y 720 は冬虫夏草由来の免疫抑制郕で、 リンパ球特異的にアポトーシスを誘導する。この薬郕を用いた動物の臓器移植で良好な成 績が得られ、欧米では臨床応用を目指した検討が進められている。他は遺伝子療法で、拒 絶反応を抑制する遗伝子を臓器に導入し、確実に抑えることである。動物実験ではFasLや CTLA4Igの遺伝子導入を行い、長期の生着が得られている。また、F T Y 720 と遺伝子 療法を組み合わせた治療法が、安全な免疫寛容の誘導に効果のあることも明らかにした。

\title{
$52-4$
}

\section{臓器移植における骨餚キメリズムと免疫寛容誘導}

\author{
筑波大学臨床医学系外科（消化器） 谷口英樹
}

骨䯣キメラにおける免疫寛容の誘導は広く知られた事実である。この免疫学的認知を背景に、 臓器移植患者におけるミクロキメリズムの成立と免疫寛容との関連性が大きな注目を集めた。 ところが、実際にはキメリズムの成立と免疫寛容の誘導は直接的には結びつかない。なぜなら、 レシピエントの胸腺中に存在するドナー抗原の総量（キメリズムの程度に規定される）により、 T細胞とストローマ細胞間のアビディティーを介して誘導される免疫寛容に差が生じるため、移 植片の生着を指標として寬容を論じればそこに闑值が存在するからである。我々は、MHCクラ スII抗原 (I-E $\alpha$ ) トランスジェニックマウスをもちいた骨㵦移植実験系を確立し、骨䯣キメリズ ムの程度と誘導される免疫䙾容の相関関倸を定量的に解析した。その結果。キメリズムの程度 とドナー反応性 $\mathrm{T}$ 細胞クローン消去の程度は反比例の関係にあること、移植片の長期生着には一 定レベル以上のキメリズムが必要であることが判明した。すなわち、 $1 \%$ 以下のミクロキメリズ 厶は移植片の生着はもたらさず、マクロキメリズムの道入を目指す必要があることを明らかに した (H.Tanlguchi,et al: J Immunol 155,5631,1995)。一方、肝移植後のキメリズム成立の 機序を明らかにする目的で、成体肝臓における造血幹細胞の存在を明らかにするとともに (H.Tanlguchi,et al: Nature Med 2,198,1996)、マウス肝移植系を用いてキメリズムの成立過 程を定量的に解析した (H.Taniguchl,et al: Transplant Proc 30.3865.1998)。その結果、肝移 植後のキメリズムはそれ単独では移植片の生着をもたらすには不十分であることが示唆された。

以上より、肝移植後には骨搉キメラが成立すること、しかし、そのキメリズムの程度は免疫 䙾容誘導には不十分であること、したがって、マクロキメリズムの導入を目指したアプローチ が必要であることが判明した。 


\section{S2-5}

造血幹細胞移植の基礎と臨床

○中畑龍俊（東大医科研）

\section{S 2-6}

生体肝移植における免疫抑制剤離脱

○猪股裕紀洋, 上本伸二, 高槻光寿, 田中紘一

(京都大学医学部移植外科)

〔目的〕生体肝移植後、長期を経過している患者に対する、免疫抑制郕の計画的な減量 · 離脱の可否を検討する。

〔方法〕1) 移植後3年以上経過、2) 肝機能正常、3) 過去1年以内に拒絶なし、の3条件を 満たし、本人または家族の了解を得た症例に対し、1993年11月よりタクロリムス の段階的な減量・離脱を試みた。減量方法はそれまで連日投与であったものを 4 回/週とし、以後3-6ヶ月間隔で3回/週、2回/週、1回/週、2回/月、1回/月と段階 的に減量していき、最終的に離脱することとした。

〔結果〕現在21例がプロトコールの対象となっており、21例中6例が最終的に離脱まで至 つた。6例とも良好な肝機能を維持しており、移植から離脱までの平均期間は74.2 ヶ月（43-98ヶ月）、離脱してから現在までの平均期間は10.3ヶ月（1-20ヶ月）で ある。現在減量中の症例は13例であり、投与状況の内訳は1回/月（1名）、2回/月 （4名）、1回/週（1名）、2回/週（2名）、3回/週（2名）、4回/週（3名）である。 2名は減量中に拒絶反応が起こり、タクロリムスを元の連日投与に戻した。2例と も拒絶の治療は容易であった。

〔結語〕慎重な症例選択、厳重な経過観察の下、計画的な免疫抑制剂の減量・離脱の可能 性が示唆された。 
RA 滑膜細胞のアポトーシスをめざした治療

○岡本 和義 1,2 、藤澤 幸史 ${ }^{1,2}$ 、西岡 久寿樹 1

( ${ }^{1}$ 聖マリアンナ医科大学・難病治療研究センター・第一部門、 ${ }^{2}$ 参天製薬・開発研)

慢性関節リウマチ (rheumatoid arhtritis: RA)は、多関節を主病変とする全身性の自己免疫疾患であ り、様々な炎症性細胞の浸潤を伴ら異常な滑膜增殖によって特徴付けられるが、その病因性明らか ではない。RA 滑膜組織の炎症性細胞および滑膜細胞は、機能的な Fas 抗原を発現し、Fas 依存性ア ポトーシスに感受性を示す。しかしながら、RA 滑膜組織ではこれらの細胞がアポトーシスにより充 分に除去されず、異常な滑膜増生が続くと考えられる。RA 滑膜組織における Fas/Fas リガンド系の 破綻が、病態形成に関与するという仮説のもと、我々は、RA 滑膜一の積極的なアポトーシス誘導が、 炎症性細胞㧍よび増殖性の滑膜細胞を除去し、関節炎を改善できると考えている。

事実、RA と非常に類似した関節炎症状を呈する HTLV-1 ウイルスの tax 遺伝子を導入したトラン スジェニックマウスに対する抗 Fas 抗体の効果を検討した結果、抗Fas抗体は滑膜細胞ならびに種々 の浸潤リンパ球にアポトーシスを誘導することによって関節炎を改善した。

さらに、我々はより生理的環境下で RA 滑膜組織にアポトーシスを誘導することを目的として、 ヒトFas リガンド遺伝子を導入した細胞を用い、RAへの治療効果を検討した。RA 滑膜組織を SCID マウスに移植したモデルを用い、ヒトFas リガンド遗伝子導入細胞を移植組織に局所注入した結果、 滑膜細胞ならびに種々の浸潤リンパ球はアポトーシスの誘導によって消失した。

以上の結果より、Fas/Fas リガンド系を介した RA 滑膜組織への積極的なアポトーシスの誘導は、 RA の有効な治療法となることが明示された。

\section{S3-2}

\section{IL-6シグナル阻害による慢性関節リウマチの治療}

○吉崎和幸 ${ }^{1}$ 、西本憲弘 ${ }^{1}$ 、松本智成 ${ }^{1}$

( ${ }^{1}$ 大阪大学健康体育部健康医学第一部門)

[目的］慢性関節リウマチ（RA）の病態にインターロイキン6（IL-6）が関与し、その阻害が RAの新しい治療法となりうることが、ヒト型化抗IL-6レセプター抗体 (rhPM-1) を用いた難治 性RA治療の成功により立証された。しかしIL-6の阻害がRAの関節組織、あるいは免疫系にどのよ うな変化を生じ治療効果を発揮するかは未だ不明である。そこでRA滑膜増殖に対するIL-6シグナ ル阻害の影響を検討した。

[方法］RA患者関節組織より分離した滑膜細胞の増殖に対するIL-6、可溶性IL-6レセプター (sIL-6R) 、 rhPM-1の作用ならびにTNF $\alpha$ との相互作用についてin vitroで検討した。またRA関 節組織をSCIDマウスに移植して作成したRAの動物モデル（SCID-HuRA）を用い、in vivoにお けるrhPM-1の治療効果を病理組織学的に解析した。

[結果] IL-6 は sIL-6Rの存在下で濃度依存性にRA滑膜細胞の増殖を抑制し、rhPM-1は IL-6/sIL-6Rによる増殖抑制作用を阻止した。TNF $\alpha$ は滑膜細胞の增殖を促したが、同時に滑膜か らのIL-6の産生を增し、この内因性IL-6がsIL-6Rの存在下で、添加IL-6と同様に増殖を抑制し TNF $\alpha$ の滑膜増殖作用と拮抗した。SCID-HuRAに対する in vivo治療実験では、rhPM-1

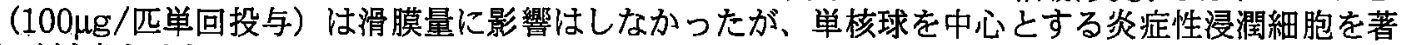
しく減少させた。

[結語］IL-6シグナル阻害による治療効果は滑膜増殖に対する直接作用ではなく炎症の除去にある。 本シンポジウムでは、RAに対するヒト型化抗IL-6レセプター抗体 (rhPM-1) の効果をin vitroお よびin vivoモデルを用いて述べる予定である。 
S 3-3

HER2を標的とした免疫治療の新しい展開：疎水化多糖類と樹状細胞 ○生田安司、王 立杰、珠玖 洋 (三重大学医学部第 2 内科)

腫瘍に対する免疫応答の解析を通じて、CD8 ${ }^{+}$CTLの重要性が明らかになると共に、 CTLの認識するMHCクラスI分子に結合した抗原ペプチドの性状も明らかになってきた。 我々は原癌遺伝子c-erbB2/HER2/neu（HER2）由来ペプチドがCD 8*CTLの標的となる ことおよび同じぺプチドが腫湯拒絶抗原であることをマウスの腫煌系で明らかにしてき た。その際同定したペプチドは日本人の約 6 割を占めるHLA-A2402に結合し、CTLの 標的になり得ることを最近明らかに出来た。一方抗原蛋白分子(標的ぺプチドを含んだ) を組み換え蛋白として作製し、個体に投与した場合には、CD 8 C C L 誘導し難い事が 多くの実験系で示されてきた。我々は最近コレステロール基を有した多糖類（プルラ ン）：疎水化多糖類と組み換え蛋白の複合体を作製することにより、蛋白分子中の MHCクラスI結合性ペプチドが抗原提示細胞内にて適切なプロセッシングを受け、 CD 8 C TLを抗原特異的に刺激することを明らかにした。HER2組み換え蛋白を用いて、 樹状細胞を抗原提示細胞として用いた我々の解析と、本複合体と樹状細胞による特異的 免疫療法の可能性について報告する。

\section{S 3-4}

樹状細胞を用いた遺伝子免疫療法

○石田 禎夫、日野田 裕治、今井 浩三 (柇幌医科大学第一内科)

【目的】癌抑制遺伝子 p53 の異常は、ほとんどのヒトの癌で平均 $50 \%$ 以上に認められる。この 変異 p53 蛋白は、正常機能を持たず、癌細胞の細胞質内に蓄積されるため、人によっては、変異 p53 ペプチドが癌細胞の MHC-Class I と結合し、CTL を誘導できる可能性がある。最近、正常組 織に発現している抗原でも、正常細胞に比して癌細胞に大量に発現していれば、癌抗原となりうる ことが報告されている。過剩発現している変異 p53 蛋白のうち、変異を含まない正常部分のエピ トープが MHC-Class I と結合できれば、正常な p53 ペプチドでワクチンが可能になる。また正常 p53 蛋白の全長を使用することにより、患者の HLA class I の種類によらずワクチン療法を行える 可能性がある。そこで野生型 p53 蛋白と樹状細胞 (Dendritic Cell ; DC) を用い、変異 p53 蛋白を もつ腫瘍への CTL の誘導を試みた。

【方法】 1) ヒトの野生型 p53 遺伝子が組み込まれたアデノウイルス (Wt-Ad-p53)を感染させた マウスの DC をマウスの腹腔内に投与して免疫し、Ras とヒト変異 p53 をトランスフェクトした NIH-3T3 細胞 (D459) を拒絶するか検討した。2) 免疫したマウスの脾細胞を用い、ヒト変異 p53 蛋白発現細胞に対する CTL を誘導できるか検討した。

【結果】1）ヒト Wt-Ad-p53 を感染させたマウスの DC で免疫されたマウスでは、85\% が D459 を拒絶した。2）拒絶したマウスでは、ヒト変異 p53 蛋白発現細胞に対する CTLが認められた。 


\title{
S 3-5
}

\author{
造血器腫瘍に対する細胞療法 \\ 高橋強志 \\ 東京大学無菌治療部
}

[目的] 慢性骨骨雄怕血病細胞では染色体相互転座により bcr/abl 融合遺伝子が存在しこ れにより bcr/abl 融合蛋白が特異的に発現している。これは、正常細胞には存在せず、腫瘍 特異的抗原である。一方、樹状細胞は強力な抗原提示細胞であり抗原未感作の $\mathrm{T}$ 細胞を効 率よく活性化できることが知られている。我々は慢性骨䯣性白血病患者樹状細胞を用いて bcr/abl 融合部分を含むぺプチドを特異的に認識する CD8 陽性 $\mathrm{T}$ 細胞の樹立を試み患者へ の応用を検討した。

[方法] bcr/abl 蛋白の融合部分を含むぺプチドをパルスした慢性骨䯣性白血病患者樹状細 胞と同患者リンパ球とを混合培養し、増殖してきた CD8 陽性 $\mathrm{T}$ 細胞を分離し更に樹状細胞 で数回刺激を繰り返し、得られた $\mathrm{T}$ 細胞の解析を行った。

[結果] 樹立された CD8 陽性 T 細胞は BCR/ABL ペプチド添加自己樹状細胞に対し HLA 拘束性に細胞障害活性を示した。また、非特異的な細胞障害活性はほとんど認められなか った。これらの結果をもとに慢性骨䯣性白血病患者に対し、樹状細胞を用いた免疫療法を 行った。現在までに、二例に治療を行っている。問題となるような急性の副作用はみられ ていない。今後、治療効果の判定、及び長期の副作用について検討していく予定である。 